\title{
Vitamin D and Autoimmune Thyroid Diseases - a Review
}

\author{
Maria Zh. Miteva ${ }^{1}$, Boyan I. Nonchev ${ }^{1}$, Maria M. Orbetzova ${ }^{1}$, Snejana D. Stoencheva ${ }^{2}$ \\ ${ }^{1}$ Second Department of Internal Diseases, Section of Endocrinology, Faculty of Medicine, Medical University of Plovdiv, St George University Hospital, \\ Plovdiv, Bulgaria \\ ${ }^{2}$ Department of Clinical Laboratory, Faculty of Pharmacy, Medical University of Plovdiv, St George University Hospital, Plovdiv, Bulgaria
}

Corresponding author: Maria Zh. Miteva, Second Department of Internal Diseases, Section of Endocrinology, Faculty of Medicine, Medical University of Plovdiv, St George University Hospital, 15A Vassil Aprilov Blvd., 4002 Plovdiv, Bulgaria; E-mail: m_miteva@yahoo.com; Tel.: 00359889242566

Received: 13 May 2019 Accepted: 8 Aug 2019 Published: 30 June 2020

Citation: Miteva MZ, Nonchev BI, Orbetzova MM, Stoencheva SD. Vitamin D and autoimmune thyroid diseases - review. Folia Med (Plovdiv) 2020;62(2):223-9. doi: 10.3897/folmed.62.e47794.

\begin{abstract}
The essential biological action of vitamin D is regulation of calcium and phosphorus metabolism and preserving bone health. In recent years there have been reports about the extraskeletal actions of vitamin D and its role in the regulation of immune system. Vitamin D supplementation appears to reduce the incidence of cardiovascular diseases, cancer, and infections and be able to reduce all-cause mortality. Deficiency of vitamin D has been found to correlate with the increased incidence of autoimmune diseases, including type 1 diabetes mellitus, rheumatoid arthritis, systemic lupus erythematosus, multiple sclerosis. Autoimmune thyroid diseases (AITD), including Graves' disease, Hashimoto's thyroiditis are relatively common autoimmune disorders affecting more than $5 \%$ of general population. It has been shown that vitamin D receptors (VDR) and 1-alpha hydroxylase are expressed in papillary thyroid cancer and normal thyroid tissue, suggesting local synthesis of $1,25(\mathrm{OH})_{2} \mathrm{D}$ in the thyroid. While VDR gene polymorphism has been found in much research to be associated with AITDs, very few studies have examined the impact of vitamin D deficiency on the incidence of AITDs in humans with conflicting results. This review focuses on the association between vitamin D and autoimmune thyroid diseases and summarizes the results of vitamin D supplementation studies in patients with AITD.
\end{abstract}

\section{Keywords}

thyroid autoimmunity, vitamin D, vitamin D supplementation

\section{INTRODUCTION}

The main role of vitamin $\mathrm{D}$ is to maintain calcium and phosphorus homeostasis and to preserve bone health. Vitamin D deficiency has become a major public health problem worldwide. There are increasing number of reports on the relationship between vitamin D deficiency and the risk of various non-skeletal disorders such as cardiovascular diseases, cancer and infections. ${ }^{1,2,4}$ It has been shown that vitamin $\mathrm{D}$ deficiency is associated with autoimmune diseases, including type 1 diabetes (T1DM) $)^{3}$, rheumatoid arthritis (RA) ${ }^{5}$, systemic lupus erythematosus (SLE) ${ }^{6}$, inflammatory bowel disease, multiple sclerosis $(\mathrm{MS})^{7}$, and that vitamin D supplementation prevents the onset and/or development of these diseases.

Low levels of vitamin D have also been associated with increased prevalence of autoimmune thyroid diseases (AITD) such as Hashimoto's thyroiditis (HT) and Graves' disease (GD). This review focuses on the possible association of vitamin D with AITD and the potential role for vitamin D supplementation in the therapy of these disorders.

\section{Physiological action of vitamin D}

Vitamin $\mathrm{D}$ is a steroid molecule which acts via vitamin $\mathrm{D}$ receptor (VDR). There are two forms of vitamin $\mathrm{D}$, cholecalciferol (vitamin $\mathrm{D}_{3}$ ) and ergocalciferol $\left(\right.$ vitamin $\mathrm{D}_{2}$ ). Vi- 
tamin $\mathrm{D}_{3}$ is synthesized in the skin by 7-dehydrocholesterol reductase upon exposure to ultraviolet $\mathrm{B}$ (UVB) radiation. It can also be obtained from a few dietary sources (mainly fatty fish). Ergocalciferol is produced by plants and fungi and represents the dietary source of vitamin D. Both forms are transported to the liver where they are hydroxylated to 25-hydroxyvitamin D (25-OH-D 3 or calcidiol). $25(\mathrm{OH})$ $\mathrm{D}$ is the major circulating and stored form of vitamin $\mathrm{D}$, and the evaluation of serum $25(\mathrm{OH}) \mathrm{D}$ is considered the best marker to measure whole body vitamin $\mathrm{D}$ status. ${ }^{8,9}$ At physiological concentrations, 25(OH)D is biologically inactive and must be converted to the biologically active form, 1,25 -dihydroxyvitamin $\mathrm{D}\left(1,25(\mathrm{OH})_{2} \mathrm{D}\right.$ or calcitriol) by $1 \alpha$-hydroxylase protein, encoded by the CYP27B1 gene and expressed mainly in the kidneys. The activity of the 1a-hydroxylase enzyme is under control of parathyroid hormone (PTH), it is down-regulated via negative feedback by calcitriol concentrations and by the fibroblast growth factor 23 (FGF 23). Calcitriol is inactivated by the 24-hydroxylase. ${ }^{8,9}$

Other cell types, including immune cells, also express $1 a$-hydroxylase and are able to convert the inactive $25(\mathrm{OH}) \mathrm{D}$ into the active $1,25(\mathrm{OH})_{2} \mathrm{D}$ in either an autocrine or paracrine manner without the above feedback regulation. ${ }^{10}$

$25(\mathrm{OH}) \mathrm{D}$ is considered as the best indicator for monitoring vitamin $\mathrm{D}$ levels. This is the major circulating form of vitamin $\mathrm{D}$ with a half-life of $2-3$ weeks. $1,25(\mathrm{OH})_{2} \mathrm{D}_{3}$ does not reflect vitamin $\mathrm{D}$ status as it has a half-life of $\sim 4 \mathrm{~h}$, peripheral levels 1000 times lower than $25(\mathrm{OH}) \mathrm{D}$ and is tightly regulated by $\mathrm{PTH}$, calcium, and phosphate.

Vitamin D receptor is an intracellular receptor which belongs to the steroid nuclear receptor family. The active $1,25(\mathrm{OH})_{2} \mathrm{D}$ form binds to the VDR and heterodimerizes with retinoic acid. This complex acts on the vitamin $\mathrm{D}$ response elements in the promotor region of target genes to exert its effects. ${ }^{9} 1,25(\mathrm{OH})_{2} \mathrm{D}$ controls the expression of genes responsible for the regulation of cellular proliferation, differentiation, apoptosis and angiogenesis. ${ }^{2}$ The brain, prostate, breast, colon tissues as well as immune cells express VDR and respond to $1,25(\mathrm{OH})_{2} \mathrm{D} .^{2} \mathrm{~A}$ form of membrane-bound VDR also exists, which would mediate immediate, non-genomic actions of $1,25(\mathrm{OH})_{2} \mathrm{D}^{8}$

Several polymorphic variants of the genes involved in metabolism, transport and activity of vitamin $\mathrm{D}$ have been described in the last years. The ones that are best characterized are the four single-nucleotide polymorphic variants of the VDR gene (Apal, Bsml, Fokl and Taql) that have been associated with autoimmune disorders or cancers. ${ }^{9}$

\section{Vitamin D and thyroid autoimmunity - molecular mechanisms}

The idea that vitamin $\mathrm{D}$ is a hormone that not only acts on the skeletal system but on a great number of target tissues has been supported by the identification of the VDR in nearly all tissue types, including the thyroid gland and human immune cells, such as neutrophils, macrophages, dendritic cells, $\mathrm{T}$ and B lymphocytes. ${ }^{2,8,10}$ Several studies indicated that the biologically active form of vitamin $\mathrm{D}$ has potent immunomodulatory effects both on the innate and adaptive immune system. ${ }^{11}$ Vitamin $\mathrm{D}$ inhibits pro-inflammatory processes by suppressing the over activity of CD4+, Th1, Th2, and Th17 cells and production of their related cytokines by the activation of VDR. Epidemiological studies have shown a relation between vitamin $\mathrm{D}$ deficiency and autoimmune diseases, such as rheumatoid arthritis, MS, SLE, type 1 diabetes, Crohn's disease. Treatment with vitamin $\mathrm{D}$ has been demonstrated to be beneficial in the management of autoimmune disorders in humans, by diminishing exacerbations of MS, reducing the pain and C-reactive protein levels in RA and psoriatic arthritis, and preventing the development of MS or T1DM when given prophylactically. $3,5,7,12$

The pathogenesis of AITDs is multifactorial, combining genetic, immune, environmental and hormonal influences. The effects of various environmental factors and the intrinsic genetic predisposition may lead to a loss of self-tolerance and promote the initiation of AITDs. ${ }^{13}$ Chronic autoimmune thyroiditis, or HT, is a typical T-cell mediated autoimmune disease, characterized by intrathyroidal infiltration of $\mathrm{B}$ and $\mathrm{T}$ lymphocytes with $\mathrm{CD} 4+$ type $1 \mathrm{~T}$ helper (Th1) subtype predominance with thyrocyte destruction and hypothyroidism. In GD, lymphocytic infiltration is mild and involves mainly CD4+type 2 T helper (Th2) cells, which induce the production of antibodies to bind the TSH receptor, indicating a humoral immune response. $^{13}$

The discovery of the vitamin $\mathrm{D}$ receptor in monocytes, dendritic cells, and activated T cells highlighted the potential involvement of vitamin $\mathrm{D}$ in the immune system and in the pathogenesis of the autoimmune diseases. ${ }^{14}$ The significant association of VDR polymorphism with AITD has also indicated a potential role of vitamin $\mathrm{D}$ in their pathogenesis. ${ }^{15}$ Dendritic cells (DC) are a primary target for the immunomodulatory activity of vitamin D. ${ }^{16}$ Vitamin D has been shown to inhibit dendritic cell dependent T-cell activation, and promote tolerogenic properties that favor the induction of regulatory rather than effector T cell. ${ }^{17} \mathrm{Ex}-$ pression of MHC II on DC is down regulated by vitamin $\mathrm{D}$, resulting in an decreased presentation of autoantigens. ${ }^{18}$ Vitamin D directly regulates T cells functions by decreasing the proliferation of Th1 and production of cytokines such as IL-2, IFN-gamma, TNF and shifting the polarization of T cells from Th1 toward Th2 that produce IL-4 and IL-5. ${ }^{19}$ A third group of Th cells, influenced by vitamin D are IL17 secreting $\mathrm{T}$ cells (Th-17 cells). 1,25(OH) $2 \mathrm{D}$ depresses IL-17 production via direct transcriptional suppression. ${ }^{14}$ The production of inflammatory Th1 cytokines promote cell-mediated cytotoxicity leading to thyroid destruction in HT. In this regard, the suppression of Th1 response by vitamin $\mathrm{D}$ may counteract the onset of GD, as Th1 dominance seems to be involved in the induction of the disease. $1,25(\mathrm{OH})_{2} \mathrm{D}$ inhibits $\mathrm{B}$ cell proliferation and differentia- 
tion into plasma cells, immunoglobulin secretion (IgG and IgM), memory B cell generation and also induces B cell apoptosis. ${ }^{10,11,14}$

Autoimmune thyroid diseases are more prevalent in women. ${ }^{20}$ Women have been reported to have higher absolute numbers of CD4+ lymphocytes and higher rates of Th1 cytokine production than men. It is also well known that estrogen stimulates calcitriol accumulation in women. ${ }^{21}$

\section{Vitamin D and AITD - clinical studies}

AITDs, including Graves' disease and Hashimoto's thyroiditis, are the most prevalent autoimmune diseases, affecting more than $5 \%$ of population. Furthermore, abnormal thyroid function varies within $7-9 \%$ in females and 1-2\% in males across different populations. A few studies have examined the relationship between vitamin D insufficiency or deficiency and prevalence of AITDs in humans.

Small case-control studies have suggested lower serum vitamin $\mathrm{D}$ levels or a higher prevalence of vitamin $\mathrm{D}$ insufficiency in patients with AITD compared with healthy controls. Kivity et al. found significantly lower levels of vitamin $\mathrm{D}$ in 50 patients with AITDs, than in 98 healthy subjects $(72 \%$ vs. $30.6 \%$; $p<0.001)$ as well as in 28 patients with HT compared to 42 patients with non-AITD (79\% vs. $52 \%$; $p<0.05)$. Vitamin D deficiency $(25(\mathrm{OH}) \mathrm{D}$ level $<25 \mathrm{nmol} / \mathrm{l})$ also correlated with the presence of antithyroid antibodies and abnormal thyroid function test $(p=0.01)$, suggesting the involvement of the hormone in the pathogenesis of the disease. ${ }^{22}$ The same association was observed by Shin et al. They reported that 111 patients with elevated anti-thyroid antibodies had lower levels of serum $25(\mathrm{OH}) \mathrm{D}_{3}$ when compared to 193 controls $(p<0.001){ }^{23}$ Tamer et al. demonstrated that 161 patients with HT had lower vitamin D levels when compared to 162 healthy age-and sex-matched controls ( $92 \%$ vs. $63 \%$; $p<0.001$ ). Moreover, vitamin D insufficiency $(<75 \mathrm{nmol} / \mathrm{l})$ occurred more frequently in patients with HT than in controls. Among the HT cases, the prevalence of vitamin $\mathrm{D}$ insufficiency tended to be higher in patients with overt hypothyroidism $(47 / 50,94 \%)$ or subclinical hypothyroidism $(44 / 45,98 \%)$ than in those with euthyroidism $(57 / 66,86 \%)$, although the differences were not statistically significant. ${ }^{24}$ The association between AITDs and hypovitaminosis $\mathrm{D}$ was also investigated in a Chinese population by Choi et al. in a cross-sectional study involving 6685 participants who underwent routine health checkups. The authors demonstrated that the levels of vitamin D were significantly lower only in Chinese pre-menopausal women with AITD, but not in postmenopausal women or in men. Vitamin D deficiency $(<25 \mathrm{nmol} / \mathrm{l})$ and insufficiency $(25-75 \mathrm{nmol} / \mathrm{l})$ were significantly associated with AITD only in premenopausal women, suggesting that vitamin D may modulate thyroid autoimmunity through estrogens. ${ }^{25}$ Unal et al. investigated 254 newly diagnosed HT and 27 GD adult patients and 124 healthy controls. They demonstrated that both HT and GD patients had lower circulating
$25(\mathrm{OH}) \mathrm{D}_{3}$ compared to healthy subjects $(p<0.001)$ and statistically significant negative correlation between vitamin $\mathrm{D}$ and anti-TPO $(r=-0.176 ; p=0.003)$, anti-TG levels $(r=$ $-0.136 ; p=0.025$ ) in both HT and GD groups and vitamin $\mathrm{D}$ levels were the lowest in GD patients. ${ }^{26}$ Bozkurt et al. revealed that serum $25(\mathrm{OH}) \mathrm{D}$ levels of HT patients $(180$ treated and 180 non-treated) were significantly lower than 180 controls, and that the severity of vitamin D deficiency was correlated with the duration of HT, thyroid volume, and antibody levels, suggesting a potential role of vitamin $\mathrm{D}$ in the development of HT and/or its progression to hypothyroidism. ${ }^{27}$ Mansournia et al. found a significant inverse association between serum 25(OH)D levels and HT (OR $0.81,95 \%$ CI $0.68-0.96$; $p=0.018$ ) by comparing 41 hypothyroid HT patients with 45 healthy euthyroid individuals, such that each $12.5 \mathrm{nmol} / \mathrm{l}$ increase in serum $25(\mathrm{OH}) \mathrm{D}$ level resulted in a $19 \%$ decrease in the odds of $\mathrm{HT}^{28}$ A recent meta-analysis of 20 case-control studies showed that AITD patients have lower $25(\mathrm{OH}) \mathrm{D}$ levels and are more likely to be vitamin $\mathrm{D}$ deficient compared to controls. ${ }^{29}$ Subgroup analyses showed that GD and HT patients also have lower $25(\mathrm{OH}) \mathrm{D}$ levels and are more likely to be deficient in vitamin $\mathrm{D}$. The criterion for vitamin $\mathrm{D}$ deficiency in the studies included in this meta-analysis was a $25(\mathrm{OH}) \mathrm{D}$ level of < 25-50 nmol/l.

The relationship between vitamin D and GD has been less investigated. Most of the available data point to a higher prevalence of $25(\mathrm{OH}) \mathrm{D}_{3}$ deficiency also at this form of thyroid autoimmunity. More pronounced decrease levels of $25(\mathrm{OH}) \mathrm{D}_{3}$ have been found mainly early after establishing the diagnosis. Kivity et al. reported higher prevalence of vitamin D deficiency in GD patients than in healthy individuals matched by age. ${ }^{22}$ In 26 female patients with newly onset GD a significant relationship of low levels of vitamin $\mathrm{D}$ with increased thyroid volume was observed, but not with anti-TSHR antibody (TRAb) levels or thyroid function, suggesting that vitamin $\mathrm{D}$ status may be involved in the pathogenesis of the disease. The same authors followed long-term development of the disease and found lower vitamin D values in 36 female GD patients in an active phase of the disease than in 18 patients with remission and 42 controls after 1 year. ${ }^{30}$ Zhang et al. revealed an association between TRAb titer and vitamin D status in GD. They found low serum vitamin D levels in TRAb-positive GD patients, suggesting that low vitamin $\mathrm{D}$ status is associated with autoimmunity in GD. ${ }^{31}$ All the data on the associations between vitamin D and GD have been reviewed in a recent meta-analysis of 26 studies by $\mathrm{Xu}$ and coworkers. The authors conclude that low vitamin D status may increase the risk of GD, however pathogenic mechanisms remains unclear. ${ }^{32}$

Association of high thyroid hormone levels with low $1,25(\mathrm{OH})_{2} \mathrm{D}_{3}$ raises the question about the molecular mechanism behind it. Thyroid hormones relatively affect renal activity of 1-alpha hydroxylase and plasma 1,25 $(\mathrm{OH})_{2} \mathrm{D}$ levels. Kozai et al. found that $\mathrm{T}_{3}$ decreases the basal transcriptional activity of the CYP 27B1 gene (1alpha hy- 
droxylase) in $\mathrm{T}_{3}$ induced hyperthyroid mice through $\mathrm{TR}$ alpha and TR beta 1 and retinoid $\mathrm{X}$ receptor alpha in renal proximal tubular cells, resulting in decreased renal CYP $27 \mathrm{~B} 1$ expression and plasma $1,25(\mathrm{OH})_{2} \mathrm{D}_{3} \cdot{ }^{33}$

Some studies, however, reported no significant association between serum vitamin D levels and thyroid autoimmunity. Goswami R et al. in a study with 642 Asian Indians, serum $25(\mathrm{OH}) \mathrm{D}$ values showed only weak inverse correlation with anti-TPO Ab titres $(r=-0.08 ; p=0.04) .{ }^{34} \mathrm{~A}$ recent study from the Amsterdam AITD cohort of 803 subjects indicated that de novo development of anti-TPO-antibodies was not associated with low vitamin D levels. The authors concluded that vitamin D deficiency is not associated with the early stages of thyroid autoimmunity. ${ }^{35}$ Chailurkit et al. in a population based survey in Thailand did not find any relationship between $25(\mathrm{OH}) \mathrm{D}$ status and thyroid autoantibodies - TgAb and TPOAb. ${ }^{36}$ D'Aurizio et al. also reported no differences in vitamin $\mathrm{D}$ deficiency $(<50 \mathrm{nmol} / \mathrm{L})$ and 25(OH)D levels between 100 AITD patients (52 HT and 48 GD) and 126 healthy controls. ${ }^{37}$

Regarding the association between functional polymorphism in the VDR gene or vitamin D binding proteins and AITD risk, the results are inconclusive. A meta analysis of eight studies including about 1000 cases of various ethnicities (Asian, European, African) indicated that the Bsml or Taql VDR polymorphism was significantly associated with AITD risk, whereas the Apal or Fokl polymorphism was not. ${ }^{15}$

\section{5(OH)D sufficiency/insufficiency/ deficiency thresholds and recommendations for supplementation}

Serum 25(OH)D level determination was recommended by the Institute of Medicine (IOM) in 1997 as the best functional indicator of vitamin D status, determined by the skin synthesis and the oral vitamin $\mathrm{D}$ ingestion. The optimal level of vitamin D remains controversial. The definition of a clinically significant vitamin $\mathrm{D}$ deficiency may vary between different populations, and is reported that serum levels depend on age, sex, and BMI and that they vary on a seasonal basis. Vitamin D deficiency is defined by the US Endocrine society guideline as $25(\mathrm{OH}) \mathrm{D}$ less than $<50$ $\mathrm{nmol} / \mathrm{l}$, vitamin D insufficiency as between $51-75 \mathrm{nmol} / \mathrm{l}^{38}$ Recently, vitamin D deficiency has become regarded as an important global health problem owing to its association with increased risk for metabolic bone diseases, as well as other chronic diseases such as diabetes mellitus, cardiovascular disease, cancer, autoimmune diseases.

According to the national multicenter cross-sectional study among 2032 subjects, conducted in Bulgaria by the Bulgarian Endocrine Society, January-February 2012, the mean serum vitamin D level in the Bulgarian female population was determined to be $36.2 \mathrm{nmol} / \mathrm{l}$, for males $41.5 \mathrm{nmol} / \mathrm{l}$, the median in serum concentration was 38.75 nmol/l. ${ }^{39}$ The threshold at which serum PTH starts to increase was applied as approach to determine the vitamin
D sufficiency. PTH in the studied Bulgarian population started to rise over the upper limit of the reference range at mean $25(\mathrm{OH}) \mathrm{D}<50 \mathrm{nmol} / \mathrm{l}$. According to this the authors defined population specific $25(\mathrm{OH}) \mathrm{D}$ sufficiency/insufficiency/deficiency thresholds. They assumed that for our population $>50 \mathrm{nmol} / \mathrm{l}$ should be defined as sufficiency or optional level, necessary for good health, insufficiency between 25-49.99 nmol/l, and deficiency $<25 \mathrm{nmol} / \mathrm{l}$. Vitamin $\mathrm{D}$ deficiency for the whole study group was $21.3 \%$, insufficiency $-54.5 \%$, and deficiency $-24.2 \%$. The level of $25(\mathrm{OH})$ $\mathrm{D}$ is not optimal (>50 nmol/l) in $75.8 \%$ of participants and the authors concluded that a great part of the population in the country is in state of deficiency and insufficiency of vitamin D. The prevalence of vitamin D insufficiency is remarkably high in women compared to that of the male population. ${ }^{39}$

According to the recommendations of Bulgarian Endocrine Society, all adults require at least 600-800 IU/daily vitamin D prophylactically. In case of deficiency and insufficiency, the dose is $1000-2000 \mathrm{IU} /$ daily to achieve a blood level of $25(\mathrm{OH}) \mathrm{D}$ of $50 \mathrm{nmol} / \mathrm{l}$. For non-skeletal effects 2000-4000 IU /daily are recommended and serum level in the range 75-110 nmol/l. In cases of chronic hyperthyroidism and uncompensated hypothyroidism 1500-2000 IU daily are needed because of the risk of development vitamin $\mathrm{D}$ deficiency.

\section{Vitamin D supplementation in autoimmune thyroid diseases}

There are several studies regarding the effects of vitamin D replacement therapy on autoimmunity with many of them focusing on thyroid autoimmunity. Agmon-Levin et al. revealed that in patients with systemic (i.e. systemic lupus erythematosus, rheumatoid arthritis, etc.) and organ-specific (i.e. multiple sclerosis, diabetes mellitus, primary biliary cirrhosis, etc.) autoimmune diseases, vitamin D levels were found to be lower when compared to healthy subjects, and that vitamin $\mathrm{D}$ supplementation had beneficial effects on autoimmune diseases. ${ }^{40}$

The positive effect of vitamin D supplementation on the treatment or prevention of AITDs has first been shown in experimental animal studies. In the first study the treatment with cyclosporin A (CsA) was potentiated by the addition of $1,25(\mathrm{OH})_{2} \mathrm{D}_{3}$ in mice with experimental autoimmune thyroiditis (EAT). When both drugs were administered at infratherapeutic doses, a lower incidence of thyroid pathology and significantly milder disease as compared to controls was observed, without alteration in the levels of anti-Tg antibodies. In addition, that study revealed that following vitamin $\mathrm{D}$ replacement therapy, the severity of histological lesions was reduced up to $26 \%$ in mice with EAT. ${ }^{41}$ In a more recent study, mice that had developed experimental autoimmune thyroiditis recovered by $44.4 \%$ after administration of low-dose vitamin D. ${ }^{42}$ It was concluded that combined use of CsA and $1,25(\mathrm{OH})_{2} \mathrm{D}_{3}$ at low doses could effectively prevent EAT with a synergistic effect. 
Mazokopakis et al. showed that serum 25(OH)D levels in 218 euthyroid HT patients were inversely correlated with anti-TPO levels. Anti-TPO levels were also significantly higher in vitamin D-deficient HT patients $(25(\mathrm{OH}) \mathrm{D}$ level $<75 \mathrm{nmol} / \mathrm{L}$ ) compared to HT patients with no vitamin D deficiency. After 4 months of oral vitamin $\mathrm{D}_{3}$ supplementation (1200-4000 IU/day) in 186 vitamin D-deficient patients, there was a significant decrease $(20.3 \%)$ in serum anti-TPO levels. ${ }^{43}$ Simsek Y et al. observed beneficial effects on anti-TPO and anti-Tg antibody titers after administration of $1000 \mathrm{IU} /$ daily vitamin D for a month in patients with AITDs and vitamin D deficiency ( $p=0.02$ and $p=0.03$, respectively) and concluded that vitamin $\mathrm{D}$ replacement may be suggested as an adjuvant treatment for AITDs, especially in those with vitamin $\mathrm{D}$ insufficiency. ${ }^{44}$ The aim of another similar study from Indian authors was to evaluate the impact of vitamin $\mathrm{D}$ supplementation on thyroid autoimmunity (TPO-Ab titers) in patients with newly diagnosed AITD in a randomized controlled trial with 102 patients. The anti-TPO levels were highest among patients in the lowest $25(\mathrm{OH}) \mathrm{D}$ quartile $(p=0.084)$. The treatment group received vitamin $\mathrm{D}$ supplementation, cholecalciferol $60000 \mathrm{U}$ once weekly for 8 weeks along with calcium 500 $\mathrm{mg} /$ daily. At 3 months of follow-up, there was a significant fall in serum TPO-Ab titers in patients of the treatment group compared to controls $(-46.73 \%$ vs. $-16.6 \%$; $p=0.028$ ). The study has demonstrated that vitamin D supplementation in therapeutic doses is associated with a significant reduction in TPO-Ab titers in patients with AITD. Subgroup analysis revealed that the quantum of reduction in TPO-Ab titers (with regards to baseline) in treatment versus control groups was significant only in patients with baseline serum TSH $\leq 10 \mathrm{mIU} / \mathrm{L}$. This may be explained by a more advanced disease state in patients with baseline TSH > $10 \mathrm{mIU} / \mathrm{L}$. The authors concluded that vitamin D supplementation in newly diagnosed AITD patients may be most beneficial in patients with early AITD $(\mathrm{TSH} \leq 10$ $\mathrm{mIU} / \mathrm{L}) .{ }^{45}$

Wang S. et al. 2018 conducted a systematic review and a meta-analysis to evaluate the effects of vitamin $\mathrm{D}$ on decreasing autoantibodies in patients with AIT. Six randomized controlled trials were included in this review representing a total of 344 patients with AIT who had been randomized to either vitamin $\mathrm{D}$ supplementation group $(n=178)$ or control group $(n=166)$. Of these patients, 330 patients had HT. One study included a mixed population of patients with HT $(n=68)$ and GD $(n=14)$. Patients with vitamin $\mathrm{D}$ insufficiency/deficiency were included in five studies. One study enrolled patients with normal $25(\mathrm{OH})$ $\mathrm{D}$ defined as $25(\mathrm{OH}) \mathrm{D}>30 \mathrm{ng} / \mathrm{ml}$. The intervention group used the following: vitamin D supplementation $1000 \mathrm{IU}$ daily, 2000 IU daily, 50000 IU once weekly in three studies, respectively, cholecalciferol 60000 IU once weekly in one study, in contrast to the other four, calcitriol $0.25 \mu \mathrm{g}$ daily was used in two studies. The duration of supplementation ranged from 1 to 6 months. LT4 was administered in five studies to maintain TSH concentrations. The re- sults showed that vitamin D supplementation significantly dropped TPO-Ab and Tg-Ab titers in short-term period (about six months). It is speculated that longer duration treatment is needed for revealing better endpoints. ${ }^{46}$

\section{CONCLUSION}

The literature review reveals many observational studies and meta-analyses which demonstrate an association between circulating levels of vitamin D and AITD. The majority of the data suggest that vitamin $\mathrm{D}$ deficiency may be associated with increased risk of thyroid autoimmunity. However, the data are still inconclusive and the authors report controversial results. The different population characteristics, seasonal variation of blood sampling, the analytical variability of vitamin $\mathrm{D}$ assays and different definitions of vitamin $\mathrm{D}$ deficiency/insufficiency contribute to the heterogeneity of the results. Some interventional trials showed that vitamin D supplementation has beneficial effects on AITDs by reducing levels of thyroid antibodies and suppressing the autoimmune reaction. Further studies are needed to reveal whether the reduction in thyroid autoantibodies is time and dose dependent, the effect of the combination vitamin D + LT4 on thyroid autoimmunity. The influence of vitamin D on other main clinical outcomes, e.g., thyroid function, ultrasound morphology and the natural course of autoimmune thyroiditis should be further evaluated. Long-term, randomized controlled trials are required to determine whether individuals with low 25(OH)D levels are at increased risk of developing thyroid autoimmunity and to provide insight into the efficacy and safety of vitamin D in the treatment of AITD.

\section{REFERENCES}

1. Makariou S, Liberopoulos EN, Elisaf M. Novel roles of vitamin D in disease: what is new in 2011? Eur J Intern Med 2011; 22(4):355-62.

2. Holick MF. Vitamin D deficiency. N Engl J Med 2007; 357(3):266-81.

3. Hyppönen E, Läärä E, Reunanen A, et al. Intake of vitamin D and risk of type 1 diabetes: a birth-cohort study. Lancet 2001; 358(9292): 1500-3.

4. Song Y, Wang L, Pittas AG, et al. Blood 25-hydroxy vitamin D levels and incident type 2 diabetes: a meta-analysis of prospective studies. Diabetes Care 2013; 36(5): 1422-8.

5. Merlino LA, Curtis J, Mikuls TR, et al. Vitamin D intake is inversely associated with rheumatoid arthritis: results from the Iowa Women's Health Study. Arthritis Rheum 2004; 50(1):72-7.

6. Kamen DL, Cooper GS, Bouali H, et al. Vitamin D deficiency in systemic lupus erythematosus. Autoimmun Rev 2006; 5(2):114-7.

7. Runia TF, Hop WC, de Rijke YB, et al. Lower serum vitamin D levels are associated with a higher relapse risk in multiple sclerosis. Neurology 2012; 79(3):261-6.

8. Wacker M, Holick MF. Vitamin D - effects on skeletal and extraskeletal health and the need for supplementation nutrients. 2013; 5(1): 111-48.

9. Kmieć P, Sworczak K. Vitamin D in thyroid disorders. Exp Clin En- 
docrinol Diabetes 2015; 123(7): 386-93.

10. Prietl B, Treiber G, Pieber TR. Vitamin D and immune function. Nutrients 2013; 5(7): 2502-21.

11. Bikle D. Nonclassic actions of vitamin D. J Clin Endocrinol Metab 2009; 94(1): 26-34.

12. Myhr KM. Vitamin D treatment in multiple sclerosis. J Neurol Sci 2009; 286(1-2): 104-8.

13. Klecha AJ, Barreiro Arcos ML, Frick L, et al. Immune-endocrine interactions in autoimmune thyroid diseases. Neuroimmunomodulation 2008; 15(1): 68-75.

14. Baeke F, Takiishi T, Korf H. Vitamin D: modulator of the immune system. Curr Opin Pharmacol 2010; 10(4): 482-96.

15. Feng M, Li H, Chen SF. Polymorphisms in the vitamin D receptor gene and risk of autoimmune thyroid diseases: a meta-analysis. Endocrine 2013; 43(2): 318-26.

16. Baeke F, Etten EV, Overbergh L, et al. Vitamin D3 and the immune system: maintaining the balance in health and disease. Nutr Res Rev 2007; 20(1): 106-18.

17. van Halteren AG, Tysma OM, van Etten E. 1alpha,25-dihydroxyvitamin D3 or analogue treated dendritic cells modulate human autoreactive $\mathrm{T}$ cells via the selective induction of apoptosis. J Autoimmun 2004; 23(3): 233-9.

18. Taher YA, van Esch BC, Hofman GA. 1alpha,25-dihydroxyvitamin D3 potentiates the beneficial effects of allergen immunotherapy in a mouse model of allergic asthma: role for IL-10 and TGF-beta. J Immunol 2008; 180(8): 5211-21.

19. Boonstra A, Barrat FJ, Crain C. 1alpha, 25-Dihydroxyvitamin d3 has a direct effect on naive $\mathrm{CD} 4(+) \mathrm{T}$ cells to enhance the development of Th2 cells. J Immunol. 2001; 167(9): 4974-80.

20. Pearce EN, Farwell AP, Braverman LE. Thyroiditis. N Engl J Med 2003; 348(26): 2646-55.

21. Gray TK, McAdoo T, Hatley L. Fluctuation of serum concentration of 1,25-dihydroxyvitamin D3 during the menstrual cycle. Am J Obstet Gynecol 1982; 144(8): 880-4.

22. Kivity S, Agmon-Levin N, Zisappl M. Vitamin D and autoimmune thyroid diseases. Cell Mol Immunol 2011; 8(3): 243-7.

23. Shin DY, Kim KJ, Kim D. Low serum vitamin D is associated with anti-thyroid peroxidase antibody in autoimmune thyroiditis. Yonsei Med J 2014; 55(2): 476-81.

24. Tamer G, Arik S, Tamer I, et al. Relative vitamin D insufficiency in Hashimoto's thyroiditis. Thyroid 2011; 21(8): 891-6

25. Choi YM, Kim WG, Kim TY. Low levels of serum vitamin D3 are associated with autoimmune thyroid disease in pre-menopausal women. Thyroid 2014; 24(4): 655-61.

26. Unal AD, Tarcin O, Parildar H. Vitamin D deficiency is related to thyroid antibodies in autoimmune thyroiditis. Cent Eur J Immunol 2014; 39(4): 493-7.

27. Bozkurt NC, Karbek B, Ucan B. The association between severity of vitamin D deficiency and Hashimoto's thyroiditis. Endocr Pract 2013; 19(3): 479-84.

28. Mansournia N, Mansournia MA, Saeedi S, et al. The association between serum 25OHD levels and hypothyroid Hashimoto's thyroiditis. J Endocrinol Invest 2014; 37(5): 473-6.

29. Wang J, Lv S, Chen G. Meta-analysis of the association between vitamin
D and autoimmune thyroid disease. Nutrients 2015; 7(4): 2485-98.

30. Yasuda T, Okamoto Y, Hamada N. Serum vitamin D levels are decreased and associated with thyroid volume in female patients with newly onset Graves' disease. Endocrine 2012; 42(3): 739-41.

31. Zhang H, Liang L, Xie Z. Low vitamin D status is associated with increased thyrotropin-receptor antibody titer in Graves' disease. Endocr Pract 2015; 21(3): 258-63.

32. Xu MY, Cao B, Yin J. Vitamin D and Graves' disease: a meta-analysis update. Nutrients 2015; 7(5): 3813-27.

33. Kozai M, Yamamoto H, Ishiguro M. Thyroid hormones decrease plasma 1a,25-dihydroxyvitamin D levels through transcriptional repression of the renal 25-hydroxyvitamin D3 1a-hydroxylase gene (CYP27B1). Endocrinology 2013; 154(2): 609-22.

34. Goswami R, Marwaha RK, Gupta N. Prevalence of vitamin D deficiency and its relationship with thyroid autoimmunity in Asian Indians: a community-based survey. Br J Nutr 2009; 102(3): 382-6.

35. Effraimidis G, Badenhoop K, Tijssen JG. Vitamin D deficiency is not associated with early stages of thyroid autoimmunity. Eur J Endocrinol 2012; 167(1): 43-8.

36. Chailurkit LO, Aekplakorn W, Ongphiphadhanakul B. High vitamin $\mathrm{D}$ status in younger individuals is associated with low circulating thyrotropin. Thyroid 2013; 23(1): 25-30.

37. D'Aurizio F, Villalta D, Metus P. Is vitamin D a player or not in the pathophysiology of autoimmune thyroid diseases? Autoimmun Rev 2015; 14(5): 363-9.

38. Holick MF, Binkley NC, Bischoff-Ferrari HA. Evaluation, treatment, and prevention of vitamin D deficiency: an Endocrine Society clinical practice guideline. Endocrine Society. J Clin Endocrinol Metab 2011; 96(7): 1911-30.

39. Borissova AM, Shinkov A, Vlahov J. Vitamin D status in Bulgariawinter data. Arch Osteoporos 2013; 8: 133.

40. Agmon-Levin N, Theodor E, Segal RM. Vitamin D in systemic and organ-specific autoimmune diseases. Clin Rev Allergy Immunol 2013; 45(2): 256-66.

41. Fournier C, Gepner P, Sadouk M. In vivo beneficial effects of cyclosporin A and 1,25-dihydroxyvitamin D3 on the induction of experimental autoimmune thyroiditis. Clin Immunol Immunopathol 1990; 54(1): 53-63.

42. Chen W, Lin H, Wang M. Immune intervention effects on the induction of experimental autoimmune thyroiditis. J Huazhong Univ Sci Technolog Med Sci 2002; 22(4): 343-5, 354.

43. Mazokopakis EE, Papadomanolaki MG, Tsekouras KC. Is vitamin D related to pathogenesis and treatment of Hashimoto's thyroiditis? Hell J Nucl Med 2015; 18(3): 222-7.

44. Simsek Y, Cakır I, Yetmis M. Effects of vitamin D treatment on thyroid autoimmunity. J Res Med Sci 2016; 21: 85.

45. Chaudhary S, Dutta D, Kumar M. Vitamin D supplementation reduces thyroid peroxidase antibody levels in patients with autoimmune thyroid disease: An open-labeled randomized controlled trial. Indian J Endocrinol Metab 2016; 20(3): 391-8.

46. Wang S, Wu Y, Zuo Z. The effect of vitamin D supplementation on thyroid autoantibody levels in the treatment of autoimmune thyroiditis: a systematic review and a meta-analysis. Endocrine 2018; 59(3): 499-505. 


\title{
Витамин D и аутоиммунные заболевания щитовидной железы - обзор
}

\author{
Мария Ж. Митева ${ }^{1}$, Боян И. Нончев ${ }^{1}$, Мария М. Орбецова $^{1}$, Снежана Д. Стоенчева ${ }^{2}$ \\ ${ }^{1}$ Вторая кафедра внутренних болезней, Секиия эндокринологии, Факультет медииинь, Медицинский университет - Пловдив, УмБАЛ „Св. \\ Георги“, Пловдив, Болгария \\ ${ }^{2}$ Кафедра клинической лабораторной диагностики, Факультет фармации, Медицинский университет - Пловдив, УМБАЛ „Св. Георги“, \\ Пловдив, Болгария
}

Адрес для корреспонденции: Мария Ж. Митева, Вторая кафедра внутренних болезней, Секция эндокринологии, Факультет медицины, Медицинский университет - Пловдив УМБАЛ „Св. Георги“, бул.“Васил Априлов“ 15A, 4002 Пловдив, Болгария, E-mail: m_miteva@yahoo.com; Тел.: 00359889242566

Дата получения: 13 мая 2019 Дата приемки: 8 августа 2019 Дата публикации: 30 июня 2020

Образец цитирования: Miteva MZ, Nonchev BI, Orbetzova MM, Stoencheva SD. Vitamin D and autoimmune thyroid diseases review. Folia Med (Plovdiv) 2020;62(2):223-9. doi: 10.3897/folmed.62.e47794.

\begin{abstract}
Абстракт
Основным биологическим действием витамина D является регуляция обмена кальция и фосфора и поддержание здоровья костей. В последние годы сообщается о воздействии витамина D вне скелетной системы и его роли в регуляции иммунной системы. Дополнительный приём витамина D, по-видимому, снижает частоту сердечно-сосудистых заболеваний, рака и инфекций и способен снизить общую смертность. Оказывается, что дефицит витамина D коррелирует с увеличением частоты аутоиммунных заболеваний, включая сахарный диабет 1 типа, ревматоидный артрит, системную красную волчанку, рассеянный склероз. Аутоиммунные заболевания щитовидной железы (АИЗЩЖ), включая болезнь Грейвса, тиреоидит Хашимото являются относительно распространёнными аутоиммунными заболеваниями, поражающими более $5 \%$ всего населения. Показано, что рецепторы витамина D (PBD) и 1-альфа-гидроксилазы экспрессируются при папиллярном раке щитовидной железы и в нормальной ткани щитовидной железы, что означает локальный синтез $1,25(\mathrm{OH})_{2} \mathrm{D}$ в щитовидной железе. В отличие от многих исследований, в которых было доказано, что полиморфизм генов PBD связан с АИЗЩЖ, в очень немногих исследованиях рассмотрено влияние дефицита витамина D на частоту возникновения АИЗЩЖ у людей с противоречивыми результатами. Этот обзор посвящён взаимосвязи между витамином D и аутоиммунными заболеваниями щитовидной железы и обобщает результаты исследований, связанных с дополнительным приёмом витамина $\mathrm{D}$ среди пациентов с АИЗЩЖ.
\end{abstract}

\section{Ключевые слова}

тиреоидный аутоиммунитет, витамин $\mathrm{D}$, дополнительный приём витамина $\mathrm{D}$ 